\title{
Influence of body mass index on patellofemoral pain
}

\author{
Influência do índice de massa corpórea na dor patelofemoral
}

\section{Influencia del índice de masa corporal en el dolor patelofemoral}

\author{
Lucas Simões Arrebola $\circledast^{[a, b]}$, Rogério Teixeira de Carvalho $\circledast^{[b]}$, \\ Vitória Cristina de Oliveira Lima ${ }^{[c]}$, Karen Alexandra Neregato Percivale ${ }^{[c]}$,

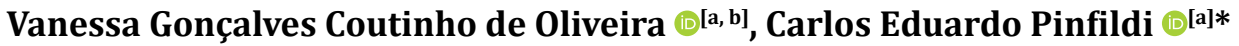 \\ [a] Universidade Federal de São Paulo (Unifesp), Santos, SP, Brazil \\ ${ }^{[b]}$ Instituto de Assistência Médica ao Servidor Público Estadual (Iamspe), São Paulo, SP, Brazil \\ ${ }^{[c]}$ Faculdades Metropolitanas Unidas (FMU), São Paulo, SP, Brazil
}

\begin{abstract}
Introduction: Patellofemoral Pain Syndrome is characterized by retro-patellar and peripatellar pain during squatting, kneeling and running whose intensity can be related to Body Mass Index (BMI). Objective: To evaluate the relationship between overweight, pain and function in women with Patellofemoral Pain Syndrome (PFPS). Method: Cross-sectional observational study of fifty-four women with PFPS assessed in the period between January and December 2015, in the physiotherapy outpatient clinic of a tertiary hospital in the city of São Paulo. To verify the variables of pain at rest, at effort and function, the Numerical Pain Rating Scale (NPRS) and the Kujala Anterior Knee Pain Scale (AKPS) were used. The participants were divided into two groups, according to the BMI categories defined by the World Health Organization (WHO): Group 1, composed of women with normal BMI (18-24.9 kg/m²), with 36 patients, and group 2 composed of overweight women $\left(25-29.9 \mathrm{k} / \mathrm{m}^{2}\right)$, with 18 patients. Comparison between groups of pain at rest and effort and AKPS were performed using Student's t-test and Mann-Witney with statistical significance p $<0,05$.
\end{abstract}

\footnotetext{
* LSA: Doctoral student, e-mail: lucasarrebola@gmail.com

RTC: PhD, e-mail: rtcarv@terra.com.br

VCOL: BS, email: vicristina96@gmail.com

KANP: BS, email: kapercivale@bol.com.br

VGCO: Master's student, email: vanessagcoliveira@gmail.com

CEP: PhD, email: cepinfildi@hotmail.com
} 
Results: There was no statistically significant difference between groups for the pain at rest and effort and for AKPS. Conclusion: BMI does not impact pain intensity and function in women with PFPS.

Keywords: Patellofemoral Pain Syndrome. Body Mass Index. Pain. Knee.

Introdução: A síndrome da dor patelofemoral (SDPF) é por dor retropatelar e peripatelar ao subir e descer escadas, ajoelhar, agachar ou correr, cuja intensidade pode estar relacionada com o Índice de Massa Corpórea (IMC). Objetivo: Avaliar a relação entre o IMC, a dor e a função em mulheres com SDPF. Método: Estudo observacional transversal de 54 mulheres com SDPF avaliadas no período entre janeiro e dezembro de 2015, no ambulatório de fisioterapia de um hospital terciário da cidade de São Paulo. Para verificação das variáveis de dor ao repouso e ao esforço, foi utilizada a Escala Numérica de Dor e para a variável função, foi utilizada a escala Kujala de dor anterior no joelho. As participantes foram divididas em dois grupos, de acordo com o IMC, seguindo os critérios da Organização Mundial de Saúde (OMS): Grupo 1, composto por mulheres com IMC normal (18-24,9 $\left.\mathrm{kg} / \mathrm{m}^{2}\right)$, com 36 pacientes, e o grupo 2 composto por mulheres com sobrepeso $\left(25-29,9 \mathrm{~kg} / \mathrm{m}^{2}\right)$, com 18 pacientes. Foi realizada a comparação das médias de dor ao repouso e ao esforço e da escala Kujala de dor anterior no joelho entre os dois grupos, por meio dos testes t.-Student para amostras independentes e Mann-Witney, considerando significância estatística $p<0,05$. Resultados: Não houve diferença estatisticamente significante entre os grupos para as variáveis de dor ao repouso, ao esforço e para a escala Kujala de dor anterior no joelho. Conclusão: O IMC não impacta na intensidade da dor e na função em mulheres com SDPF.

Palavras-chave: Síndrome da Dor Patelofemoral. Índice de Massa Corporal. Dor. Joelho.

\section{Resumen}

Introducción: El síndrome de dolor patelofemoral (SDPF) se caracteriza por dolor retropatelar y peripatelar al subir y bajar escaleras, arrodillarse o correr, cuya intensidad puede estar relacionada con el Índice de Masa Corporal (IMC). Objetivo: Evaluar la relación entre el IMC, el dolor y la función en mujeres con SDPF. Método: Estudio observacional transversal con 54 mujeres con SDPF evaluadas en el período entre enero y diciembre de 2015, en el ambulatorio de fisioterapia de un hospital terciario de la ciudad de São Paulo. Para verificación de las variables de dolor al reposo y al esfuerzo, se utilizó la Escala Numérica de Dolor, y para la variable función, se utilizó la escala Kujala de dolor existente en la rodilla. Las participantes se dividieron en dos grupos, de acuerdo con el IMC, siguiendo los criterios de la Organización Mundial de la Salud (OMS): grupo 1 compuesto por mujeres con IMC normal (18-24,9 kg/m $\left.{ }^{2}\right)$ con 36 pacientes, y el grupo 2 compuesto por mujeres con sobrepeso (25-29,9 $\mathrm{kg} / \mathrm{m}^{2}$ ) con 18 pacientes. Se realizó la comparación de los promedios de dolor al reposo y al esfuerzo y de la escala entre los grupos, por medio de la prueba $t$ de Student para las muestras independientes y de la prueba de Mann-Whitney, considerando significancia estadística $p<0,05$. Resultados: No hubo diferencia estadísticamente significativa entre los grupos para las variables dolor al reposo, al esfuerzo y a la escala Kujala de dolor existente en la rodilla. Conclusión: El IMC no impacta en la intensidad del dolor y en la función de mujeres con SDPF.

Palabras clave: Síndrome de Dolor Patelofemoral. Índice de Masa Corporal. Dolor. Rodilla.

\section{Introduction}

Patellofemoral pain syndrome (PFP) is characterized by retropatellar and peripatellar pain while climbing up and down stairs, kneeling, squatting, or running, which can cause limitations to daily and sports activities [1, 2]. PFP accounts for $25 \%$ to $45 \%$ of all knee problems in active individuals [3], with higher incidence and prevalence in women [4]. Its etiology is multifactorial and may be related to direct trauma, mechanical overload at the joint, altered patellar alignment due to anatomical 
variations and muscular imbalances, degenerative changes, or a combination of these factors, affecting the distribution of forces acting on the knee joint $[5,6]$.

The patellofemoral joint plays a key role in the function of the knee because it increases the extensor torque by $30 \%$ in the end of the movement range and is responsible for absorbing the axial load during daily life activities, in which it can be submitted to forces equivalent to 2 to 3 times the body weight $[7,8]$.

The number of overweight or obese women has increased in recent years, especially in developing countries [9], making this population more susceptible to knee osteoarthritis (OAJ) and PFP [10], as the increase in body mass and associated metabolic factors may increase the mechanical demand and generate excessive stress on the articular cartilage of the knee, leading to a degenerative process $[11,12]$.

Despite the possible relationship between body weight and mechanical joint overload, the relationship between a high BMI and the development of PFP is controversial [8]. Regardless of this association, a conservative treatment approach recommends that individuals with knee pain lose weight, as this may lead to the improvement of pain and function related to this joint, as well as reduce the progression of joint degeneration $[13,14]$.

There is no consensus in the literature regarding the relationship between weight loss and improvement of pain and function in individuals with PFP, nor are there studies that relate a high BMI to the intensity of pain and dysfunction in this population. Based on these facts, the objective of the present study was to evaluate the relationship between BMI, pain and function in women with PFP.

\section{Methods}

\section{Study Design}

Observational cross-sectional study of women with PFP that attended the physiotherapy outpatient clinic of a tertiary hospital in the city of São Paulo.

\section{Procedures}

Women diagnosed with PFP, unilateral or bilateral, by an orthopedist through clinical examination and imaging, were included in the study. All participants signed the Free and Informed
Consent Term with orientation about the study, which was approved by the institution's Ethics and Research Committee (Reference no: 808.433) on October 14, 2014.

The inclusion criteria were: women aged 18 to 43 years, irregularly active according to the International Physical Activity Questionnaire (IPAQ) criteria [15], with a history of previous knee pain for at least three months and increased pain in at least two SDPF-related activities, such as going up and down stairs, jumping, squatting, or standing for a long period with the knee flexed. The exclusion criteria were male subjects, women who had any degree of gonarthrosis, or women who had undergone any type of surgical procedure in the spine or lower limbs.

Each participant had their BMI calculated by self-report of weight and height, according to Dekkers etal. [16]. For statistical purposes, participants were divided into two groups. Group 1 was composed of women with normal BMI $\left(18-24.9 \mathrm{~kg} / \mathrm{m}^{2}\right)$ and group 2 was composed of overweight women $\left(25-29.9 \mathrm{~kg} / \mathrm{m}^{2}\right)$ according to the World Health Organization (WHO) criteria. [17]

The pain was assessed through the numerical pain rating scale (NPRS) at rest and during effort, considered as climbing up and down stairs and squatting [18], and the knee function was assessed through the Kujala Anterior Knee Pain Scale (AKPS) [19]. The NPRS is composed of 11 points in which 0 corresponds to the absence of pain and 10 to the worst pain imaginable. The Kujala AKPS is composed of 13 items and scored from 0 to 100, the highest value corresponding to the best function.

Statistical analysis

For statistical analyses, the individuals were allocated into two groups: group 1 (G1), composed of women with normal BMI (BMI between 18$24.9 \mathrm{~kg} / \mathrm{m}^{2}$ ) and group 2 (G2), composed of overweight women (BMI between $25-29.9 \mathrm{~kg} / \mathrm{m}^{2}$ ). For the statistical analysis, the program $\mathrm{R}$ version 3.4.2 for Windows was used, with the Shapiro-Wilk and Levene tests to evaluate the normality and homogeneity assumptions and Student's t-tests for independent samples with a normal distribution. The Mann-Whitney test was used for data with nonnormal distribution. Statistical significance was considered at $\mathrm{p}<0.05$. 


\section{Results}

The sample consisted of 54 women with PFP: 36 in G1 and 18 in G2. The mean age of G1 participants was 29.11 ( \pm 8.33) years and that of the G2 participants was 28.58 ( \pm 9.41 ) years. The difference between the groups in terms of the weight, height, and BMI was verified by means of the Student's t-test for independent samples and, for age, the Mann-Whitney test was used. A statistically significant difference was observed in terms of weight and BMI. The characteristics of the subjects are described in Table 1.

Table 1 - Characteristics of the study subjects

\begin{tabular}{lccc}
\hline \multicolumn{1}{c}{ Variable } & G1 $(\mathbf{n}=\mathbf{3 6})$ & G2 $(\mathbf{n}=\mathbf{1 8})$ & P value \\
\hline Age $(\mathrm{y})$ & $29.11(8.33)$ & $28.58(9.41)$ & 0.9131 \\
Weight $(\mathrm{kg})$ & $59.17(7.85)$ & $72.23(5.53)$ & $<0.001$ \\
Height $(\mathrm{m})$ & $1.64(0.07)$ & $1.63(0.05)$ & 0.3443 \\
BMl $\left(\mathrm{kg} / \mathrm{m}^{2}\right)$ & $21.87(2.19)$ & $26.98(2.20)$ & $<0.001$ \\
\hline
\end{tabular}

Note: y: year; kg: kilogram; m: meter; BMl: body mass index; $\mathrm{kg} / \mathrm{m}^{2}$ : kilogram/squared meter; G1: Group 1; G2: Group 2.

The difference between the means of the pain score at rest of G1 $(3.67 \pm 2.74)$ and G2 $(3.64 \pm 3.12)$ and pain during effort of G1 $(6.73 \pm 2.09)$ and G2 $(6.47 \pm 2)$ were verified by the non-parametric Mann-Whitney test; no statistically significant difference was noted between the groups. The difference between the means of the Kujala AKPS of G1 $(60.77 \pm 12.81)$ and G2 (62.79 \pm 17.73$)$ was verified through the Student's t-test for independent samples. The assumptions of this method, namely normality and homogeneity, were evaluated using the Shapiro-Wilk and Levene tests, respectively. No statistically significant difference in the comparison of these variables was noted (Table 2).

Table 2 - Comparison of pain and function between groups

\begin{tabular}{lccc}
\hline \multicolumn{1}{c}{ Variable } & Gl $(\boldsymbol{n}=\mathbf{3 6})$ & $\mathbf{G 2}(\mathbf{n}=\mathbf{1 8})$ & $\mathbf{P}$ value \\
\hline NPRS at rest & $3.96(2.67)$ & $4.08(3.26)$ & 0.9634 \\
NPRS during effort & $6.68(2.16)$ & $6.69(2)$ & 0.538 \\
Kujala AKPS & $63.39(11.03)$ & $63.38(16.53)$ & 0.6305 \\
\hline
\end{tabular}

Note: NPRS: numerical pain rating scale; AKPS: anterior knee pain scale; G1: Group 1; G2: Group 2.

\section{Discussion}

The main finding of this study was that there is no influence of BMI on the intensity of pain and knee function of women with PFP. To the best of our knowledge, this was the first study to evaluate the impact of BMI on pain and function in individuals already diagnosed with PFP.

Overweight generates a systemic inflammatory condition in which cytokines known as adiposins are secreted by the adipose tissue into systemic circulation, causing inflammation of various body tissues. Adiposins, especially leptin, adiponectin, and resistin play a key role in the pathophysiology of $\mathrm{OAJ}$ [20]. Reduction of body mass enables a decrease in pain and disability associated with joint degeneration present in $\mathrm{OAJ}$, and most guidelines recommend weight loss for symptom improvement. Studies have shown an improvement of approximately $40 \%$ in pain and function, with a $10 \%$ reduction in body mass $[21,22]$. It is known that the decrease in body mass in overweight and OAJ subjects can lead to pain reduction, increase function, and reduce the progression of joint degeneration [11, 14, 23]. Conversely, a systematic review has shown that there is no relationship between BMI and the risk of developing PFP, both in adolescents and adults [8]. These findings are comparable to those of this study, wherein it was found that weight and BMI may not influence pain and function in the enrolled population. It is worth noting that the included subjects comprised irregularly active women who were different in terms of only weight and BMI.

Although there is a possible relationship between increased BMI and stress and structural deformation of the articular cartilage $[8,11]$ and weight loss, it is frequently recommended by orthopedists treating knee related dysfunctions, therapeutic strategies only addressing this relationship may not be able to affect the whole spectrum of symptoms associated with PFP as evidenced by the results obtained in this study. The chronic pain present in PFP is the result of a complex and dynamic interaction between physiological, biomechanical, and social factors that cause the persistence of or worsening condition. For establishing the most effective approach and an understanding of this condition, there is a need for a biopsychosocial investigation, aiming to globally address all aspects that may be present in pain $[24,25]$.

A conservative treatment approach for PFP patients takes into account the biomechanical dysfunction characterized by increased adduction and medial rotation of the hip in closed kinetic chain and delayed activation of the vastus medial in open kinetic chain and involves strengthening the muscles 
of the hip and quadriceps response to ameliorate the pain and improve function in this condition $[3,26,27,28]$. Mechanical overload and stress on the cartilage of the patellofemoral joint may occur due to a decrease in the contact area generated by these biomechanical changes, which are independent of BMI [29].

The objective of this study was to verify if BMI influences the intensity of pain and knee function in women with PFP, by means of a transversal study. No type of treatment was proposed for the participants in this study. However, we cannot rule out that overweight has no impact on the pain and dysfunction symptoms especially when some type of treatment is proposed. Furthermore, the increase in body mass may be detrimental to the knee joint because it generates several alterations that can compromise the function and lead to significant structural changes that in the long term can necessitate joint replacement [30]. There is no correlation between overweight and the risk of developing PFP [8]. Moreover, the findings of this study demonstrate that there is no relationship between overweight and pain intensity and dysfunction present in PFP; however, there is still the possibility of overweight and obese individuals being more susceptible to OAJ development.

This study has two main limitations. Men with PFP were not evaluated as PFP is more prevalent in women. Furthermore, no individuals with a BMI above $29.9 \mathrm{~kg} / \mathrm{m}^{2}$ were evaluated. Hence the results and conclusions present in this study only account for overweight women and not for other degrees of obesity. There is thus a need for further studies to verify the influence of BMI on the conservative treatment outcomes of PFP, as well as the impact of other degrees of obesity on the magnitude of pain and dysfunction in individuals with PFP.

\section{Conclusion}

Higher BMI does not have an impact on pain intensity and function in irregularly active women with PFP.

\section{Acknowledgments}

We thank the team of Orthopedics and Traumatology and the Physiotherapy team of the Institute of Medical Assistance to the State Public Servant for making this work possible.

\section{References}

1. Dutton RA, Khadavi MJ, Fredericson $M$. Patellofemoral Pain. Phys Med Rehabil Clin N Am. 2016;27(1):31-52.

2. Khayambashi K, Mohammadkhani Z, Ghaznavi K, Lyle M, Powers CM. The effects of isolated hip abductor and external rotator muscle strengthening on pain, health Status, and hip strength in females with patellofemoral pain: a randomized controlled trial. J Orthop Sports Phys Ther. 2012;42(1):22-9.

3. Crossley KM, Van Middelkoop M, Callaghan MJ. Patellofemoral pain consensus statement from the 4th International Patellofemoral Pain Research Retreat, Manchester. Part 2: recommended physical interventions (exercise, taping, bracing, foot orthoses and combined interventions). Br J Sports Med. 2016;50(14):844-52.

4. Dolak KL, Silkman C, McKeon JM, Hosey RG, Lattermann C, Uhl TL. Hip strengthening prior to functional exercises reduces pain sooner than quadriceps strengthening in females with patellofemoral pain syndrome: a randomized clinical trial. J Orthop Sports Phys Ther. 2011;41(8):560-70.

5. Yildiz Y, Apaydin AH, Seven MM, Orscelik A. The effects of prolotherapy (hypertonic dextrose) in recreational athletes with patellofemoral pain syndrome. J Exp Integr Med. 2016;6(2):53-6.

6. Petersen W, Ellermann A, Rembitzki IV, Scheffler S, Herbort M, Brüggeman GP, et al. Evaluating the potential synergistic benefit of a realignment brace on patients receiving exercise therapy for patellofemoral pain syndrome: a randomized clinical trial. Arch Orthop Trauma Surg. 2016;136(7):975-82.

7. Loudon JK. Biomechanics and pathomechanics of the patellofemoral joint. Int J Sports Phys Ther. 2016;11(6):820-30.

8. Hart HF, Barton CJ, Khan KM, Riel H, Crossley KM. Is body mass index associated with patellofemoral pain and patellofemoral osteoarthritis? A systematic review and meta-regression and analysis. Br J Sports Med. 2017;51(10):781-90. 
9. Ng M, Fleming T, Robinson M, Thomson B, Graetz $\mathrm{N}$, Margono C, et al. Global, regional, and national prevalence of overweight and obesity in children and adults during 1980-2013: a systematic analysis for the Global Burden of Disease Study 2013. Lancet. 2014;384(9945):766-81.

10. Sridhar MS, Jarrett CD, Xerogeanes JW, Labib SA. Obesity and symptomatic osteoarthritis of the knee. J Bone Joint Surg Br. 2012;94(4):433-40.

11. Viester L, Verhagen EA, Oude Hengel KM, Koppes LL, van der Beek AJ, Bongers PM. The relation between body mass index and musculoskeletal symptoms in the working population. BMC Musculoskelet Disord. 2013;14:238.

12. Silvernail JF, Milner CE, Thompson D, Zhang S, Zhao X. The influence of body mass index and velocity on knee biomechanics during walking. Gait Posture. 2013;37(4):575-9.

13. Jones BQ Covey CJ, Sineath MH Jr. Nonsurgical management of knee pain in adults. Am Fam Physician. 2015;92(10):875-83.

14. Gersing AS, Schwaiger BJ, Nevitt MC, Joseph GB, Chanchek N, Guimaraes JB, et al. Is weight loss associated with less progression of changes in knee articular cartilage among obese and overweight patients as assessed with MR imaging over 48 months? Data from the osteoarthritis initiative. Radiology. 2017;284(2):508-20.

15. Craig CL, Marshall AL, Sjostrom M, Bauman AE, Booth ML, Ainsworth BE, et al. International physical activity questionnaire: 12 -country reliability and validity. Med Sci Sports Exerc. 2003;35(8):1381-95.

16. 16. Dekkers JC, van Wier MF, Hendriksen IJ, Twisk JW, van Mechelen W. Accuracy of self-reported body weight, height and waist circumference in a Dutch overweight working population. BMC Med Res Methodol. 2008;8:69.

17. World Health Organization. Physical status: the use and interpretation of anthropometry. Report of a WHO Expert Committee. WHO Technical Report Series 854. Geneva: World Health Organization; 1995.
18. Chesworth BM, Culham E, Tata GE, Peat M. Validation of outcome measures in patients with patellofemoral syndrome. J Orthop Sports Phys Ther. 1989;10(8):302-8.

19. Kujala UM, Jaakkola LH, Koskinen SK, Taimela S, Hurme M, Nelimarkka O. Scoring of patellofemoral disorders. Arthroscopy. 1993;9(2):159-63.

20. Belluzzi E, El Hadi H, Granzotto M, Rossato M, Ramonda R, Macchi V, et al. Systemic and Local Adipose Tissue in Knee Osteoarthritis. J Cell Physiol. 2017;232(8):1971-8.

21. Messier SP, Mihalko SL, Legault C, Miller GD, Nicklas BJ, DeVita P, etal. Effects of intensive diet and exercise on knee joint loads, inflammation, and clinical outcomes among overweight and obese adults with knee osteoarthritis: the IDEA randomized clinical trial. JAMA. 2013;310(12):1263-73.

22. Atukorala I, Makovey J, Lawler L, Messier SP, Bennell K, Hunter DJ. Is there a dose-response relationship between weight loss and symptom improvement in persons with knee osteoarthritis? Arthritis Care Res. 2016;68(8):1106-14.

23. Felson DT, Zhang Y, Anthony JM, Naimark A, Anderson JJ. Weight loss reduces the risk for symptomatic knee osteoarthritis in women: the Framingham study. Ann Intern Med. 1992;116(7):535-9.

24. Taylor AM, Phillips K, Patel KV, Turk DC, Dworkin $\mathrm{RH}$, Beaton D, et al. Assessment of physical function and participation in chronic pain clinical trials: IMPACT/OMERACT recommendations. Pain. 2016;157(9):1836-50.

25. Gatchel RJ, McGeary DD, McGeary CA. Interdisciplinary chronic pain management: past, present, and future. Am Psychol. 2014;69(2):119-30.

26. Nakagawa TH, Moriya ET, Maciel CD, Serrão FV. Trunk, pelvis, hip and knee kinematics, hip strength, and gluteal muscle activation during a single-leg squat in males and females with and without patellofemoral pain syndrome. J Orthop Sports Phys Ther. 2012;42(6):491-501. 
27. Briani RV, Silva DO, Pazzinatto MF, Ferreira AS, Ferrari D, Azevedo FM. Delayed onset of electromyographic activity of the vastus medialis relative to the vastus laterallis may be related to physical activity levels in females with patellofemoral pain. J Electromyogr Kinesiol. 2016;26:137-42.

28. Rothermich MA, Glaviano NR, Li J, Hart JM. Patellofemoral pain: epidemiology, pathophysiology, and treatment options. Clin Sports Med. 2015;34(2):313-27.

29. Souza RB, Draper CE, Fredericson M, Powers CM. Femur rotation and patellofemoral joint kinematics: a weightbearing magnetic resonance imaging analysis. J Orthop Sports Phys Ther. 2010;40(5):277-85.
30. Apold H, Meyer HE, Nordsletten L, Furnes O, Baste V, Flugsrud GB. Weight gain and the risk of knee replacement due to primary osteoarthritis: a population based, prospective cohort study of 225.908 individuals. Osteoarthritis Cartilage. 2014;22(5):652-8.

Received in 10/26/2018

Recebido em 26/10/2018

Recibido em 26/10/2018

Approved in 07/01/2020

Aprovado em 07/01/2020

Aprobado en 07/01/2020 